\title{
Talking With Your Child 1
}

\section{Kate Fogarty, Evelyn Rooks-Weir, and Millie Ferrer ${ }^{2}$}

One of the most important things that your child must learn is how to talk. On average, a child will say his or her first word at 12 months of age and may start speaking anywhere from 8 to 18 months of age. Between 18 months and 2 years, your toddler will speak in two-word "sentences." By the time your child reaches 3 years, he or she will have a large vocabulary and at 6 years will know about 10,000 words and be a capable conversationalist.

Your child's language skills show how well his or her brain and thought processes are developing. Children also develop emotionally and build social skills through conversation. In fact, early language skills help children to adjust more easily to difficult circumstances. Toddlers with advanced language development are more likely to do well socially, academically, and behaviorally in later childhood (Rhule, 2006).

How and when your child's language develops depends on the circumstance. For example, girls vocabulary grows faster than boys. Cautious toddlers who are more reserved may take more time to understand words before they begin to speak.
There are many ways you can help your child learn to talk. This can be done by finding natural opportunities in everyday situations to encourage communication. Here are a couple of suggestions to help your child's language skills to develop.

- From the moment your child is born, talk to your baby. You can call the child's name, and sing to him or her.

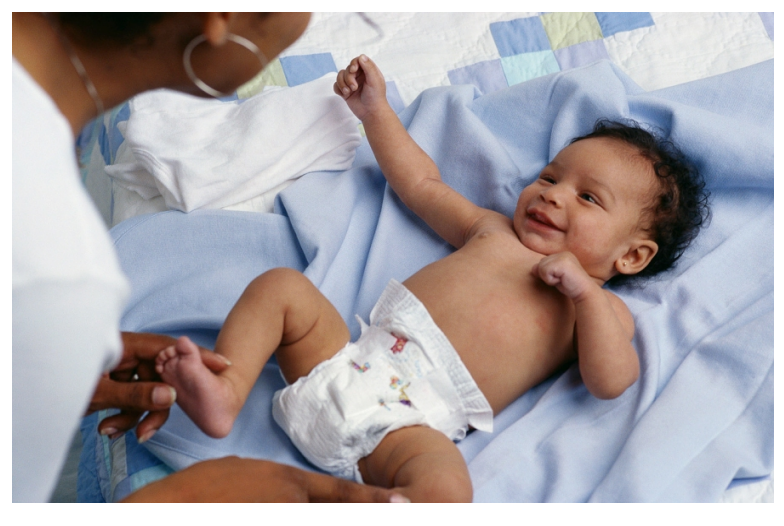

- Use "child-directed speech" (CDS). CDS involves speaking in a high pitched voice, using short sentences, pausing between phrases, annunciating clearly, using expressive emotional tones, and repeating new words in different contexts.

1. This document is FCS2006, one of a series of the Family Youth and Community Sciences Department, Florida Cooperative Extension Service, Institute of Food and Agricultural Sciences, University of Florida. Original publication date November 1, 1988. Revised June 12, 2006. Visit the EDIS Web Site at http://edis.ifas.ufl.edu.

2. Revised 2006 by Kate Fogarty, Ph.D., assistant professor youth development, Department of Family, Youth and Community Sciences. Written by Evelyn Rooks-Weir, former associate professor, Human Development, revised by Millie Ferrer, Ph.D., associate professor, Human Development, Department of Family, Youth and Community Sciences, Cooperative Extension Service, Institute of Food and Agricultural Sciences, University of Florida, Gainesville, 32611.

The Institute of Food and Agricultural Sciences (IFAS) is an Equal Opportunity Institution authorized to provide research, educational information and other services only to individuals and institutions that function with non-discrimination with respect to race, creed, color, religion, age, disability, sex, sexual orientation, marital status, national origin, political opinions or affiliations. U.S. Department of Agriculture, Cooperative Extension Service, University of Florida, IFAS, Florida A. \& M. University Cooperative Extension Program, and Boards of County Commissioners Cooperating. Larry Arrington, Dean 
- Talk to your baby during daily routines such as when you cuddle, feed, or change diapers.

- Repeat the noises your baby makes and encourage him or her to imitate the sounds you make.

- Call your baby's name often. Remember to point out objects to the baby and call them by name. Say to the baby, "See the chair, see the bird, see the truck."

- Refer to what you're doing during daily activities. For example say, "It's time to change your diaper." Or "We're eating breakfast."

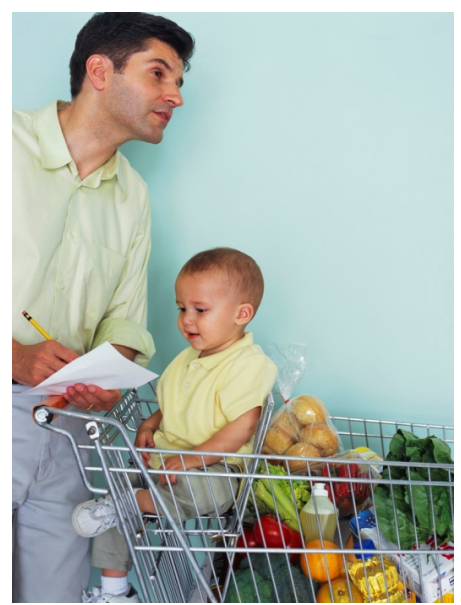

- When your baby becomes a toddler, teach him or her names of emotions they feel. "You're angry because we can't play now. It's time for bed." "I know the doggie scared you. The dog went outside."

- Remember, your baby has to learn the names of as many objects, routines, actions, and emotions as possible.

- When your child begins to talk, listen to him or her. Avoid correcting or using phrases like, "It's NOT goed, it's went!" Instead, simply repeat what the child said, pronouncing the words correctly and using the correct grammar. Children make natural mistakes when they are learning grammar (such as past tense putting "ed" endings on all verbs). They will learn the exceptions to the rules when they are ready and taught with patience.

- Avoid asking your child yes or no questions. For example, ask, "Do you want milk or juice?" In this way, your child can answer using names of the object or activity they choose.

- Help your child learn new words every day. Soon, he or she will begin to ask questions about objects ("What?").

- Your child will also ask about cause and effect ("Why?"). Do not ignore his or her questions, Instead, try to answer them. If you do not know the answers, tell your child that you don't know. Share the answers using simple words or a cause and effect explanation.

If you want your children to talk with you when they are older, remember to talk with them when they are young. Conversations are an important part of quality parent-child relationships. Warm communication that encourages your childs cognitive, social and emotional skills lasts a lifetime.

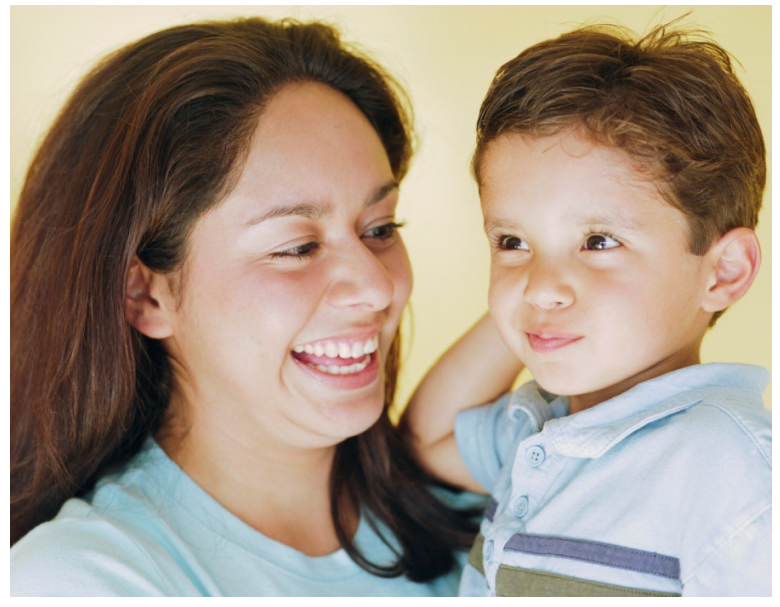

References:

Berk, L.E. (2006). Child Development (2 ${ }^{\text {nd }}$ Edition). Boston: Allyn \& Bacon.

Nicholas, J.G. (2006). Effects of early auditory experience on the spoken language of deaf children at 3 years of age. Ear \& Hearing, 27, 286-298.

Rhule, D., McMahon, R., Spieker, S., \& Munson, J. (2006). Positive adjustment and associated protective factors of children with adolescent mothers. Journal of Child \& Family Studies, 15, 224-244. 